\title{
PENGETAHUAN, SIKAP DAN PERILAKU KADER POSYANDU DALAM PENIMBANGAN BALITA SELAMA PANDEMI COVID-19 DI JAKARTA TIMUR
}

\author{
Paramita Boni Lestari dan Dian Ayubi \\ Universitas Indonesia, Depok, Jawa Barat, Indonesia \\ Email: paramitaboni2@gmail.com dandian_ayb@ui.ac.id
}

\begin{tabular}{l}
\hline ARTIKEL INFO \\
\hline Tanggal diterima: 5 April 2021 \\
Tanggal revisi: 15 April 2021 \\
Tanggal yang diterima: 25 \\
April 2021 \\
\hline
\end{tabular}

Keywords:

attitude; covid-19; knowledge; practice; weighing

\begin{abstract}
The behavior of cadres in weighing toodlers during the COVID-19 pandemic is very important. The behavior of cadres in carrying out their duties can help detect growth abnormalities of toddlers and prevent transmission of COVID19 to posyandu visitors. The purpose of this study was to determine the relationship between knowledge and attitudes towards cadres' behavior in weighing toddlers at posyandu during the COVID-19 pandemic. This research is an analytical study with a cross sectional research design. The sample in this study was the toddler posyandu cadres who weighed toddlers at the posyandu in August 2020, totaling 100 people. Data collection using a questionnaire in the form of gform. Data analysis used univariate analysis (frequency distribution table) and bivariate analysis (chi square test). The results found that $89 \%$ of posyandu cadres for toddlers had a good level of knowledge, 69\% had a positive attitude and $77 \%$ had good practice in weighing toddlers during the COVID-19 pandemic. The chi square test showed that there was no significant relationship between knowledge and attitudes towards posyandu cadres' practice (p-value> 0.05). The conclusion is that there is no relationship between knowledge and attitudes towards cadres' behavior, but cadres have good knowledge, positive attitudes and good behavior in weighing toddlers.
\end{abstract}

\begin{abstract}
ABSTRAK
Perilaku kader dalam melakukan penimbangan balita selama masa pandemi COVID-19 sangat penting. Perilaku kader dalam menjalankan tugas dapat membantu mendeteksi kelainan pertumbuhan balita dan mencegah penularan COVID-19 pada pengunjung posyandu. Tujuan penelitian ini yaitu ingin mengetahui hubungan antara pengetahuan dan sikap terhadap perilaku kader posyandu dalam melakukan penimbangan balita di posyandu pada masa pandemi COVID19. Penelitian ini merupakan penelitian analitik dengan desain penelitian cross sectional. Sampel pada penelitian ini adalah kader posyandu balita yang melakukan penimbangan balita di posyandu pada bulan Agustus 2020 yang berjumlah 100 orang. Pengumpulan data menggunakan kuesioner dalam bentuk google form. Analisis data menggunakan analisis univariat
\end{abstract}

Lestari, Paramita Boni, et. al. (2021) Pengetahuan, Sikap dan Perilaku Kader Posyandu dalam Penimbangan Balita Selama Pandemi Covid-19 Di Jakarta Timur. Jurnal Health Sains 2(4). http://jurnal.healthsains.co.id/index.php/jhs/article/view/154 2723-6927 Ridwan Institute 
(tabel distribusi frekuensi) dan analisis bivariat (uji chi square). Hasil pada penelitian ini didapatkan bahwa $89 \%$ kader posyandu balita memiliki tingkat pengetahuan baik, 69\% memiliki sikap yang positif dan $77 \%$ berperilaku baik dalam melakukan penimbangan balita pada masa pandemi COVID19. Hasil uji chi square menunjukkan bahwa tidak ada hubungan yang signifikan antara pengetahuan dan sikap terhadap perilaku kader posyandu (p-value > 0,05). Kesimpulan dari penelitian ini adalah tidak ada hubungan

Kata Kunci:

covid-19; pengetahuan; penimbangan; perilaku; sikap antara pengetahuan dan sikap terhadap perilaku kader, namun kader memiliki pengetahuan yang baik, sikap yang positif serta perilaku yang baik dalam melakukan penimbangan balita.

\section{Pendahuluan}

COVID-19 merupakan penyakit yang masih menjadi permasalahan kesehatan dunia. COVID-19 yaitu penyakit yang disebabkan oleh virus Sars-Cov-2. Ada indikasi dari penyakit COVID- 19, yakni gangguan pernafasan, demam, batuk serta sesak nafas (RI, 2020). Data WHO per tanggal 31 Juli 2020, secara global terdapat 17.106 .007 orang terkonfirmasi positif, dengan jumlah kematian sebesar 292.527 orang. Di Indonesia, kasus awal ditemui pada 2 Maret 2020. Data per 31 Juli 2020, terdapat 106.336 orang terkonfirmasi positif dengan total kematian sebanyak 5.058 orang.

DKI Jakarta ialah provinsi dengan kasus paling tinggi di Indonesia. Per tanggal 20 Agustus 2020 dengan angka positif terbanyak ada di daerah Jakarta Timur sebanyak 4175 kasus terkonfirmasi positif. Gubernur DKI Jakarta pada tanggal 25 Februari 2020 mengeluarkan Instruksi Gubernur DKI Jakarta No 16 Tahun 2020 tentang Peningkatan Kewaspadaan terhadap Resiko Penularan Infeksi Corona Virus Disease (COVID-19). Pada 9 April 2020 Pemerintah DKI Jakarta menerbitkan Peraturan Gubernur No 33 Tahun 2020 tentang Penerapan Pembatasan Sosial Berskala Besar yang mulai berlaku pada 10 April 2020. Peraturan tersebut menghimbau warga Jakarta untuk senantiasa di rumah serta meniadakan aktivitas diluar hingga 23 April 2020.
Salah satu akibat pandemi COVID- 19 adalah terganggunya pelayanan kesehatan terutama pelayanan kesehatan pada bayi (RI, 2020). Cakupan pelayanan kesehatan balita terendah terdapat di DKI Jakarta $(<91 \%)$. Cakupan pelayanan balita di Jakarta Timur mencapai 90,6\%. Pelayanan kesehatan pada balita meliputi pemantauan tumbuh kembang balita lewat penimbangan balita tiap bulan. Penimbangan bayi bisa dilakukan di posyandu, sarana kesehatan ataupun dirumah. Selama masa pandemi COVID-19, terdapat kebijakan terkait pelaksanaan penimbangan balita di posyandu.

Cakupan balita yang ditimbang di Jakarta Timur menempati posisi 4 besar terendah ialah 71,04\% (Dinkes DKI Jakarta, 2019).

Kader memiliki peran penting dalam penerapan posyandu. Kader disini bertugas memfasilitasi, mempersiapkan serta menyelenggarakan posyandu. Keberhasilan pelaksanaan penimbangan balita di posyandu bergantung kepada pengetahuan, perilaku serta sikap kader dalam melakukan penimbangan balita. Tidak hanya pengetahuan tentang penimbangan balita, namun juga perilaku serta sikap dalam penimbangan balita selama masa pandemi. Berdasarkan penelitian terdahulu yang dilakukan oleh (Listyaningsih et al., 2016; Mardhiyah et al., 2017; O'Brien et al., 2016; Sifaq et al., 2020)bahwa semakin baik pengetahuan dan sikap kader maka semakin 
baik juga pelayanan posyandu yang diberikan. Penelitian tersebut dilakukan pada masa sebelum pandemi COVID-19. Sedangkan selama pandemi COVID-19 terdapat pelayanan yang disesuaikan sehingga penulis ingin melihat bagaimana pengetahuan, perilaku, serta sikap kader posyandu dalam melaksanakan penimbangan bayi di posyandu yang di Jakarta Timur pada bulan Agustus 2020.

\section{Metode Penelitian}

Penelitian ini merupakan penelitian analitik dengan desain penelitian cross sectional. Penelitian dilakukan mulai tanggal 28 November 2020 s/d 8 Desember 2020. Variabel pada penelitian ini meliputi pengetahuan, sikap dan perilaku kader posyandu dalam melakukan penimbangan balita di posyandu selama masa pandemi pada bulan Agustus 2020. Populasi dalam penelitian ini adalah semua kader aktif posyandu di Jakarta Timur sebanyak 8402 kader. Besar sampel berjumlah 100 responden dihitung menggunakan rumus Lemeshow. Pengambilan sampel yang dipilih secara purposive random sampling. Pengumpulan data dilakukan dengan menggunakan google form dan aplikasi Whatsapp. Data yang sudah terkumpul dilakukan editing, koding, entry data dan cleaning. Analisis data pada penelitian ini adalah analisis univariat dan bivariat. Analisis univariat menggunakan tabel frekuensi pada masing-masing variabel. Sedangkan analisis bivariat menggunakan uji chi square.

\section{Hasil dan Pembahasan}

\section{A. Hasil Penelitian}

Analisis univariat dilakukan untuk melihat gambaran pada masing-masing variabel. Baik pada variabel dependent maupun independent. Hasil disajikan dalam distribusi frekuensi setiap variabel yaitu karakteristik responden, tingkat pengetahuan, sikap dan perilaku kader posyandu.

B. Pembahasan

\section{Karakteristik Responden}

Hasil penelitian pada tabel 1 menunjukkan bahwa responden paling banyak berusia $40 \mathrm{~s} / \mathrm{d} 50$ tahun (49\%). Sebanyak $75 \%$ responden telah menjadi kader lebih dari 5 tahun dan 69\% kader berpendidikan terakhir SMA.

Tabel 1

Distribusi Karakteristik Responden

\begin{tabular}{lcc}
\hline \multicolumn{1}{c}{ Karakteristik Responden } & $\mathrm{n}$ & $\%$ \\
\hline Umur Responden & & \\
\hline 36-45 Tahun & 30 & 30 \\
\hline 46-55 Tahun & 49 & 49 \\
\hline >56 Tahun & 21 & 21 \\
\hline Lama Menjadi Kader & & \\
\hline <=5 Tahun & 28 & 28 \\
\hline >5 Tahun & 72 & 72 \\
\hline Pendidikan Terakhir Kader & & \\
\hline SMP & 11 & 11 \\
\hline SMA & 69 & 69 \\
\hline Diploma III & 12 & 12 \\
\hline S1 & 7 & 7 \\
\hline S2 & 1 & 1 \\
\hline \multicolumn{2}{r}{ Sumber: Data Primer, 2020} &
\end{tabular}

Sumber: Data Primer, 2020

a) Gambaran Perilaku, Pengetahuan dan Sikap Kader Posyandu dalam Penimbangan Balita di Posyandu Selama Masa Pandemi COVID-19

Hasil univariat pada masingmasing variabel disajikan dalam bentuk tabel distribusi frekuensi. Hasil dapat dilihat pada tabel 2, 3, dan 4 di bawah ini.

Tabel 2

Distribusi Responden Menurut Butir-Butir Perilaku Kader Tentang Prosedur Penimbangan Balita di Posyandu Selama Masa Pandemi COVID-19 di Bulan Agustus 2020

\begin{tabular}{|c|c|c|}
\hline Unsur Perilaku & $\overline{Y a}$ & Tidak \\
\hline $\begin{array}{l}\text { Koordinasi dengan } \\
\text { Satgas COVID-19 } \\
\text { tingkat RW }\end{array}$ & $97(97 \%)$ & $3(3 \%)$ \\
\hline $\begin{array}{l}\text { Identifikasi Sasaran } \\
\text { sebelum Posyandu }\end{array}$ & $\begin{array}{c}100 \\
(100 \%) \\
\end{array}$ & $0(0 \%)$ \\
\hline Menyusun Jadwal & 100 & $\underline{0(0 \%)}$ \\
\hline
\end{tabular}




\begin{tabular}{|c|c|c|}
\hline Posyandu & $(100 \%)$ & \\
\hline $\begin{array}{l}\text { Mengumumkan Hari } \\
\text { Buka Posyandu }\end{array}$ & $\begin{array}{c}100 \\
(100 \%)\end{array}$ & $0(0 \%)$ \\
\hline Menyiapkan APD & $62(62 \%)$ & $38(38 \%)$ \\
\hline $\begin{array}{l}\text { Menyiapkan Sarana } \\
\text { dan Prasarana }\end{array}$ & $70(70 \%)$ & $30(30 \%)$ \\
\hline $\begin{array}{l}\text { Memeriksa Suhu } \\
\text { Tubuh Pengunjung } \\
\text { Posyandu }\end{array}$ & $62(62 \%)$ & $38(38 \%)$ \\
\hline $\begin{array}{l}\text { Mengarahkan } \\
\text { Pengunjung untuk } \\
\text { CTPS }\end{array}$ & $80(80 \%)$ & $20(20 \%)$ \\
\hline $\begin{array}{l}\text { Desinfeksi Alat } \\
\text { Pengukur BB setiap } 1 \\
\text { orang pengukuran }\end{array}$ & $67(67 \%)$ & $\begin{array}{c}33 \\
(33 \%)\end{array}$ \\
\hline $\begin{array}{l}\text { Melengkapi dokumen } \\
\text { pencatatan dan } \\
\text { pelaporan }\end{array}$ & $\begin{array}{c}100 \\
(100 \%)\end{array}$ & $0(0 \%)$ \\
\hline $\begin{array}{l}\text { Sweeping untuk } \\
\text { sasaran yang tidak } \\
\text { hadir }\end{array}$ & $69(69 \%)$ & $\begin{array}{c}31 \\
(31 \%)\end{array}$ \\
\hline $\begin{array}{l}\text { Penyampaian laporan } \\
\text { ke Puskesmas }\end{array}$ & $\begin{array}{c}100 \\
(100 \%)\end{array}$ & $0(0 \%)$ \\
\hline
\end{tabular}

Sumber: Data Primer, 2020

\begin{tabular}{lcr}
\multicolumn{1}{c}{ Perilaku } & kader & $\begin{array}{r}\text { yang } \\
\text { adalah }\end{array}$ \\
tingkat \\
kemampuan & kader & untuk \\
memberikan & pelayanan & terkait
\end{tabular}
penimbangan balita di posyandu selama masa pandemi pada bulan Agustus 2020. Variabel perilaku kader dalam penimbangan balita diukur dengan 12 pertanyaan. Pada tabel 2 diketahui bahwa seluruh kader mengidentifikasi sasaran (jumlah balita dan identitas balita) sebelum dilakukan posyandu, menyusun jadwal posyandu, mengumpulkan hari buka posyandu melalui grub WA tingkat RT masing-masing kader, melengkapi dokumen pencatatan dan pelaporan, dan menyampaikan laporan hasil penimbangan ke petugas gizi puskesmas. Hal ini sejalan dengan petunjuk teknis pelaksanaan posyandu selama masa pandemi COVID-19. Namun ada butir perilaku yang masih kurang yaitu tidak menyiapkan APD (sarung tangan) dan memeriksa suhu tubuh pengunjung $(38 \%)$.
Tabel 3

Distribusi Responden Menurut Butir-Butir Pengetahuan Tentang Penimbangan Balita di Posyandu Pada Masa Pandemi COVID-19 di Bulan Agustus 2020

\begin{tabular}{|c|c|c|}
\hline $\begin{array}{c}\text { Butir-butir } \\
\text { Pengetahuan }\end{array}$ & Benar & Salah \\
\hline $\begin{array}{l}\text { Prosedur CTPS yang } \\
\text { benar }\end{array}$ & $100(100 \%)$ & $0(0 \%)$ \\
\hline $\begin{array}{l}\text { Pengertian 3M } \\
\text { dalam Pencegahan } \\
\text { COVID-19 } \\
\end{array}$ & $100(100 \%)$ & $0(0 \%)$ \\
\hline $\begin{array}{l}\text { Manfaat Menjaga } \\
\text { Jarak }\end{array}$ & $88(88 \%)$ & $2(2 \%)$ \\
\hline $\begin{array}{l}\text { Suhu Tubuh } \\
\text { Terindikasi COVID- } \\
19\end{array}$ & $57(57 \%)$ & $43(43 \%)$ \\
\hline $\begin{array}{l}\text { Etika Batuk dan } \\
\text { Bersin }\end{array}$ & $99(99 \%)$ & $1(1 \%)$ \\
\hline $\begin{array}{l}\text { Persiapan Sebelum } \\
\text { posyandu }\end{array}$ & $91(91 \%)$ & $9(9 \%)$ \\
\hline $\begin{array}{l}\text { Jumlah Maksimal } \\
\text { Pengungjung yang } \\
\text { hadir }\end{array}$ & $82(82 \%)$ & $18(18 \%)$ \\
\hline $\begin{array}{l}\text { Syarat Kader yang } \\
\text { Bertugas }\end{array}$ & $86(86 \%)$ & $14(14 \%)$ \\
\hline $\begin{array}{l}\text { Syarat Pengunjung } \\
\text { yang hadir }\end{array}$ & $86(86 \%)$ & $14(14 \%)$ \\
\hline $\begin{array}{l}\text { Sweeping Peserta } \\
\text { yang tidak hadir }\end{array}$ & $76(76 \%)$ & $24(24 \%)$ \\
\hline $\begin{array}{l}\text { Bulan Penimbangan } \\
\text { Balita }\end{array}$ & $100(100 \%)$ & $0(0 \%)$ \\
\hline
\end{tabular}

Sumber: Data Primer, 2020

Pengetahuan yang diukur meliputi pengetahuan umum tentang pencegahan COVID-19 dalam melakukan penimbangan balita di posyandu selama masa pandemi COVID-19. Variabel pengetahuan diukur dengan menggunakan 11 pertanyaan. Pada tabel 3 dapat dilihat bahwa seluruh responden menjawab benar pada butir pengetahuan prosedur CTPS yang benar $(100 \%)$, pengertian $3 \mathrm{M}$ dalam pencegahan COVID-19 (1005), dan bulan penimbangan balita $(100 \%)$. Sebanyak $43 \%$ kader tidak mengetahui suhu tubuh yang terindikasi COVID-19. 


\section{Tabel 4}

Distribusi Responden Menurut Butir-Butir Sikap Kader tentang Penimbangan Balita di Posyandu Selama Masa Pandemi COVID-19 Pada Bulan Agustus 2020

\begin{tabular}{|c|c|c|c|c|}
\hline Unsur Sikap & $\begin{array}{l}\text { Sangat } \\
\text { Setuju }\end{array}$ & Setuju & $\begin{array}{c}\text { Tidak } \\
\text { Setuju }\end{array}$ & $\begin{array}{l}\text { Sangat } \\
\text { Tidak } \\
\text { Setuju } \\
\end{array}$ \\
\hline $\begin{array}{l}\text { Perlunya koordinasi } \\
\text { Ke Satgas COVID- } \\
19 \text { Tingkat RW } \\
\end{array}$ & $59(59 \%)$ & $40(40 \%)$ & $0(0 \%)$ & $1(1 \%)$ \\
\hline $\begin{array}{l}\text { Perlunya identifikasi } \\
\text { sasaran (balita) } \\
\text { Sebelum } \\
\text { Posyandu } \\
\end{array}$ & $6(6 \%)$ & $66(66 \%)$ & $24(24 \%$ & $4(4 \%)$ \\
\hline $\begin{array}{l}\text { Perlunya persiapan } \\
\text { APD }\end{array}$ & $49(49 \%)$ & $45(45 \%)$ & $6(6 \%)$ & $0(0 \%)$ \\
\hline $\begin{array}{l}\text { Perlunya persiapan } \\
\text { Sarana Prasarana }\end{array}$ & $55(55 \%)$ & $44(44 \%)$ & $\begin{array}{c}0 \\
(0 \%)\end{array}$ & $1(1 \%)$ \\
\hline Perlunya skrining & $42(42 \%)$ & $45(45 \%)$ & $\mathbf{8}(\mathbf{8 \%})$ & $5(5 \%)$ \\
\hline $\begin{array}{l}\text { Perlunya } \\
\text { pembatasan Jumlah } \\
\text { Pengunjung }\end{array}$ & $24(24 \%)$ & $59(59 \%)$ & $12(12 \%$ & $5(5 \%)$ \\
\hline $\begin{array}{l}\text { Perlunya pelaporan } \\
\text { Hasil }\end{array}$ & $37(37 \%)$ & $62(62 \%)$ & $1(1 \%)$ & $0(0 \%)$ \\
\hline
\end{tabular}

Sumber: Data Primer, 2020

Sikap merupakan pernyataan responden terhadap penimbangan balita pada masa pandemi COVID19. Variabel sikap diukur dengan menggunakan 7 pertanyaan. Pada tabel 4 menunjukkan bahwa responden sangat setuju terhadap perlunya koordinasi ke satgas COVID-19 tingkat RW (59\%), perlunya persiapan APD (49\%), perlunya persiapan sarana prasarana (55\%) serta perlunya pelaporan hasil penimbangan balita (62\%).

b) Hubungan antara Pengetahuan dan Sikap terhadap Perilaku Kader Posyandu dalam Penimbangan Balita di Posyandu pada Masa Pandemi COVID-19

Hasil analisis bivariat pada variabel pengetahuan terhadap perilaku dan variabel sikap terhadap perilaku kader posyandu dapat dilihat pada tabel 5 di bawah ini:

\section{Tabel 5}

\section{Hubungan Antara Pengetahuan dan Sikap Terhadap Perilaku Kader dalam Penimbangan Balita di Posyandu Selama Masa Pandemi COVID-19 Pada Bulan} Agustus 2020

\begin{tabular}{|c|c|c|c|c|c|c|c|c|}
\hline \multirow{2}{*}{ Variabel } & \multirow{2}{*}{ Perilaku } & \multicolumn{2}{|c|}{ Baik } & \multicolumn{2}{|c|}{ Cukup } & \multicolumn{2}{|c|}{ Total } & \multirow[t]{2}{*}{ p-value } \\
\hline & & $\mathrm{n}$ & $\%$ & $\mathrm{n}$ & $\%$ & $\mathbf{n}$ & $\%$ & \\
\hline \multirow[b]{2}{*}{ Pengetahuan } & Baik & 68 & 68 & 21 & 21 & 89 & 100 & \multirow[b]{2}{*}{0,514} \\
\hline & Kurang & 9 & 9 & 2 & 2 & 11 & 100 & \\
\hline \multirow[b]{2}{*}{ Sikap } & Positif & 56 & 56 & 13 & 13 & 69 & 100 & \multirow[b]{2}{*}{0,223} \\
\hline & Negatif & 21 & 21 & 10 & 10 & 31 & 100 & \\
\hline
\end{tabular}

Perilaku merupakan wujud nyata dari suatu tindakan (overt behavior). Kategori perilaku kader dibagi menjadi tiga, yaitu perilaku baik $(\geq 9)$, perilaku cukup (5 s/d 8) dan perilaku kurang $(<5)$. Tabel 5 dapat dilihat bahwa $77 \%$ responden berperilaku baik dalam melakukan penimbangan balita. Berdasarkan data variabel perilaku kader posyandu diperoleh skor tertinggi 12; skor terendah 5; Mean 9,82;

Median 11; dan Standar Deviasi 2,307.

Pengetahuan merupakan hasil dari penginderaan suatu objek. Penginderaan bisa melibatkan berbagai alat indera seperti indera mata, telinga, pengecapan dan sebagainya. Pengetahuan dapat mempengaruhi perilaku seseorang untuk bertindak. Ada dua kategori pada variabel pengetahuan yaitu pengetahuan baik $(\geq$ 9) dan pengetahuan kurang (< 9). Tingkat pengetahuan kader mengenai prosedur penimbangan balita berada pada kategori baik (89\%). Berdasarkan data variabel pengetahuan kader posyandu diperoleh skor tertinggi 11; skor terendah 6; Mean 9,91; Median 10; dan Standar Deviasi 1,147.

Pada tabel 5 memperlihatkan bahwa kader yang berpengetahuan baik, 68\%-nya berpengetahuan baik dan $9 \%$ berpengetahuan kurang. Responden yang memiliki pengetahuan baik sebagian besar memiliki perilaku yang baik dalam penimbangan balita selama masa pandemi COVID-19. Hal ini sejalan dengan penelitian yang dilakukan oleh (Sihombing et al., 2020) 
yang menyebutkan bahwa perilaku yang didasari oleh pengetahuan yang baik akan lebih bertahan dibanding dengan pengetahuan yang kurang. Sejalan dengan penelitian yang dilakukan oleh (Afiati et al., 2017), dengan pengetahuan yang baik maka seseorang akan lebih menaruh perhatian lebih terhadap suatu perilaku tertentu. Dari hasil uji statistik menunjukkan nilai $\mathrm{p}>0.05$ sehingga dapat disimpulkan bahwa tidak ada hubungan bermakna antara pengetahuan dengan perilaku kader posyandu.

Sikap merupakan predisposisi suatu perilaku yang belum diwujudkan dalam suatu tindakan. Sikap diukur dengan menggunakan skala likert (sangat setuju, setuju, tidak setuju, sangat setuju) dengan skor 1-4. Kategori sikap dibagi menjadi dua yaitu sikap positif ( $\geq 22$ atau 70\%) dan sikap negatif $(<22$ atau $70 \%)$. Sikap kader tentang prosedur penimbangan balita di posyandu ada pada kategori positif (69\%). Berdasarkan data variabel sikap kader posyandu diperoleh skor tertinggi 28; skor terendah 15; Mean 922,89; Median 23; dan Standar Deviasi 2,449. Pada kader yang berperilaku baik, 56\%-nya memiliki sikap positif dan 21\%-nya bersikap negatif. Menurut penelitian yang dilakukan oleh (Nouman et al., 2012) di Quetta Pakistan menyebutkan bahwa sikap positif seseorang dapat mengarahkan kepada perilaku yang baik. Dari hasil uji statistik menunjukkan nilai $\mathrm{p}>0.05$ sehingga dapat disimpulkan bahwa tidak ada hubungan bermakna antara sikap dengan perilaku kader posyandu.

Penelitian ini menemukan tidak ada hubungan antara pengetahuan dan sikap terhadap perilaku kader dalam melakukan penimbangan. Hal ini didukung oleh penelitian yang dilakukan oleh (Shima et al., 2017) di Iran dan (Mohammed et al., 2019) di Malaysia, yang menyebutkan bahwa perilaku tidak hanya dipengaruhi oleh pengetahuan dan sikap, namun juga dipengaruh oleh faktor lain seperti pendidikan, pekerjaan dan pengalaman responden.

\section{Kesimpulan}

Berdasarkan hasil penelitian didapatkan bahwa tingkat pengetahuan kader posyandu masuk dalam kategori baik (89\%). Butir pengetahuan yang perlu ditingkatkan lagi yaitu pengetahuan mengenai suhu tubuh terindikasi COVID-19. Kader posyandu memiliki sikap yang positif dalam penimbangan balita di masa pandemi COVID-19 (69\%). Perilaku kader posyandu masuk dalam kategori baik dalam melakukan penimbangan balita (77\%). Namun ada butir perilaku yang tidak dilakukan oleh kader posyandu, seperti menyiapkan APD dan melakukan pemeriksaan suhu tubuh. Hasil uji statistik ditemukan bahwa tidak ada hubungan yang signifikan antara pengetahuan dan sikap kader posyandu terhadap perilaku kader posyandu dalam penimbangan balita. Berdasarkan hasil penelitian, peneliti merekomendasikan perlu adanya refereshing kader tentang penimbangan balita selama masa pandemi COVID-19 mengingat adanya beberapa kader yang masih belum menjawab dengan benar pada butir pengetahuan, serta beberapa perilaku penimbangan balita yang belum dilakukan oleh kader posyandu selama penimbangan balita pada masa pandemi COVID-19. Pemberian informasi mengenai kesehatan dan refreshing terbukti mampu meningkatkan pengetahuan kader (Chahyanto et al., 2019; Mamuaja et al., 2015; Sidiq, 2018; Solehati et al., 2018; Wahyuningsih \& Sari, 2015). 


\section{BIBLIOGRAFI}

Afiati, R., Adhani, R., Ramadhani, K., \& Diana, S. (2017). Hubungan Perilaku Ibu Tentang Pemeliharaan Kesehatan Gigi Dan Mulut Terhadap Status Karies Gigi Anak Tinjauan Berdasarkan Pengetahuan, Tingkat Pendidikan, Dan Status Sosial Di Tk Aba 1 Banjarmasin Kajian Di Puskesmas Kota Banjarmasin Bulan September-Oktob. Dentino: Jurnal Kedokteran Gigi, 2(1), 56-62. Google Scholar

Chahyanto, B. A., Pandiangan, D., Aritonang, E. S., \& Laruska, M. (2019). Pemberian Informasi Dasar Posyandu Melalui Kegiatan Penyegaran Kader Dalam Meningkatkan Pengetahuan Kader Di Puskesmas Pelabuhan Sambas Kota Sibolga. Action: Aceh Nutrition Journal, 4(1), 7-14. Google Scholar

Listyaningsih, K. D., Widyastuti, D. E., \& Mareta, M. Y. (2016). Hubungan Antara Tingkat Pengetahuan Kader Dengan Sikap Kader Tentang Posyandu Balita Di Desa Pengkok Kedawung Sragen. Jurnal Kesehatan Kusuma Husada. Google Scholar

Mamuaja, V. A., Kawengian, S., \& Sondakh, R. (2015). Hubungan Antara Sosial Ekonomi Keluarga Dengan Asupan Energi Siswa Kelas 4 Dan Kelas 5 Sdn 1 Tounelet Dan Sd Katolik St. Monica Kecamatan Langowan Barat. Jurnal Administrasi Publik, 4(32). Google Scholar

Mardhiyah, A., Sha'ban, M., \& Azhim, A. (2017). Evaluation Of Histological And Biomechanical Properties On Engineered Meniscus Tissues Using Sonication Decellularization. 2017 39th Annual International Conference Of The Ieee Engineering In Medicine And Biology Society (Embc), 2064-2067. Google Scholar

Mohammed, G. H., Colombo, R., Middleton, E. M., Rascher, U., Van Der Tol, C.,
Nedbal, L., Goulas, Y., Pérez-Priego, O., Damm, A., \& Meroni, M. (2019). Remote Sensing Of Solar-Induced Chlorophyll Fluorescence (Sif) In Vegetation: 50 Years Of Progress. Remote Sensing Of Environment, 231, 111177. Google Scholar

Nouman, W., Siddiqui, M. T., Basra, S. M. A., Khan, R. A., Gull, T., Olson, M. E., \& Hassan, M. (2012). Response Of Moringa Oleifera To Saline Conditions. International Journal of Agriculture And Biology, 14(5). Google Scholar

O'brien, J., Lee, S.-H., Onogi, S., \& Shea, K. J. (2016). Engineering The Protein Corona Of A Synthetic Polymer Nanoparticle For Broad-Spectrum Sequestration And Neutralization Of Venomous Biomacromolecules. Journal Of The American Chemical Society, 138(51), 16604-16607. Google Scholar

Ri, K. (2020). Pedoman Pencegahan Dan Pengendalian Coronavirus Disease (Covid-19)'. Kemenkes Ri, O-115. Google Scholar

Shima, H., Matsumoto, M., Ishigami, Y., Ebina, M., Muto, A., Sato, Y., Kumagai, S., Ochiai, K., Suzuki, T., \& Igarashi, K. (2017). S-Adenosylmethionine Synthesis Is Regulated By Selective N6Adenosine Methylation And Mrna Degradation Involving Mettl16 And Ythdc1. Cell Reports, 21(12), 33543363. Google Scholar

Sidiq, R. (2018). Efektivitas Penyuluhan Kesehatan Dalam Meningkatkan Pengetahuan Kader Posyandu Tentang Pencegahan Pneumonia Pada Balita. Action: Aceh Nutrition Journal, 3(1), 22-27. Google Scholar

Sifaq, A., Kusuma, I. D. M. A. W., Wahyudi, A. R., Khamidi, A., \& Yuhantini, E. F. (2020). The Effect Of Plank Training With The Concept Of Training From Home During The Covid-19 Pandemic. Journal Of Physical Education Health And Sport, 7(2), 38-42. Google Scholar 
Sihombing, C. M., Efendy, I., \& Hadi, A. J. (2020). Faktor Yang Mempengaruhi Perilaku Penyedia Makanan Terhadap Pelaksanaan Perilaku Hidup Bersih Dan Sehat Di Warung Kecamatan Panyabungan. Window of Health: Jurnal Kesehatan, 18-27. Google Scholar

Solehati, T., Trisyani, M., \& Kosasih, C. E. (2018). Gambaran Pengetahuan, Sikap,
Dan Keluhan Tentang Menstruasi Diantara Remaja Puteri. Jurnal Keperawatan Komprehensif (Comprehensive Nursing Journal), 4(2), 86-91. Google Scholar

Wahyuningsih, E., \& Sari, L. P. (2015). Hubungan Kadar Hemoglobin Dengan Kejadian Dismenore Pada Siswi Kelas Xi Sma Negeri 1 Wonosari Klaten. Involusi Jurnal Ilmu Kebidanan, 4(7). Google Scholar

\section{Copyright holder:}

Paramita Boni Lestari dan Dian Ayubi (2021)

First publication right:

Jurnal Health Sains

This article is licensed under:

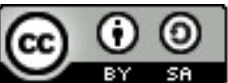

